Yang $\mathcal{E}$ Campos, 2020

Volume 5 Issue 3, pp. 925-939

Date of Publication: 26 $6^{\text {th }}$ February 2020

DOI- $h$ ttps://doi.org/10.20319/pijss.2020.53.925939

This paper can be cited as: Yang, W. B. E Campos, M. R. A. (2020). Factors Affecting Customer Satisfaction in International Hotels in Chenzhou City, China. PEOPLE: International Journal of Social Sciences, 5(3), 925-939.

This work is licensed under the Creative Commons Attribution-Non Commercial 4.0 International License. To view a copy of this license, visit http://creativecommons.org/licenses/by-nc/4.0/ or send a letter to Creative Commons, PO Box 1866, Mountain View, CA 94042, USA.

\title{
FACTORS AFFECTING CUSTOMER SATISFACTION IN INTERNATIONAL HOTELS IN CHENZHOU CITY, CHINA
}

\author{
Wen Bo Yang \\ Graduate Studies in Business, College of Business Administration and Accountancy, De La Salle \\ University-Dasmarinas, Dasmarinas City, Philippines \\ ywx0058@dlsud.edu.ph \\ Maria Rebecca A. Campos \\ Graduate Studies in Business, College of Business Administration and Accountancy, De La Salle \\ University-Dasmarinas, Dasmarinas City, Philippines \\ cmaribec@yahoo.com
}

\begin{abstract}
The significance of the customer satisfaction management in the hotel industry has been demonstrated by many researchers in the past decades. This study determined the relationship between five key factors (hotel facilities, service capability, service efficiency, service attitude, and breakfast) to the degree of the customer satisfaction with the hotel. These factors were conceptualized from the five dimensions of tangibility, reliability, responsiveness, assurance, and empathy in the SERVQUAL model proposed by Parasuraman, Zeithamal \& Berry (1988). Empirical research was conducted in one of the international hotels in Chenzhou City, Hunan Province, China, focusing on the hotel's customer satisfaction management. The data were taken from the two online reservation websites that reviewed the hotel based on the SERVQUAL model from 2017 to 2018. Multiple linear regression analysis was used to determine the relationship between the five key factors and the degree of customer satisfaction based on about 1,500 online comments. Only two (service capability and service attitude) of the five key factors turned out to
\end{abstract}


have significant positive effects on the customer satisfaction in this hotel. Two other factors (hotel facilities and breakfast) have no significant positive effects, while service efficiency has an unexpected no significant negative effect on this hotel's customer satisfaction. This study offers some suggestions for improving the future decision-making for the customer satisfaction management of this hotel and also provides a guide for other enterprises experiencing the similar situation with the mutual benefits for avoiding the mistakes in customer satisfaction management so as to improve the overall performance of the hotel.

\section{Keywords}

Customer Satisfaction, Hotel, China, Service Capability, Service Attitude

\section{Introduction}

This chapter introduces the research background, the research questions, the research objectives, the research significance, the scope and the limitations of this study, and provides the theoretical framework as well as the literature review.

\subsection{Research Background}

There is no doubt that the degree of success in customer satisfaction management will influence the hotel's overall performance. However, it seems that the management team of the Chenzhou W-H-International Hotel hasn't paid much attention to its customer satisfaction management and continued committing some mistakes in its three years of successful operation at the cost of a huge dropdown on the occupancy rate from $90 \%$ to $50 \%$ and its customer satisfaction from 4.8/5.0 to 4.2/5.0. This situation is happening not only in the hotel industry, but also in many start-up enterprises which are ignoring the importance of customer satisfaction management and facing the survival crisis at the same time. In this study, an empirical research was conducted with the development of the SERQUAL model involving statistic measurements (multiple linear regression analysis) of the factors affecting the customer satisfaction. This determined the relationship between five key factors (including hotel's facilities, service capability, service efficiency, service attitude, and breakfast) and the degree of the customer satisfaction level of the hotel. These five key factors were conceptualized from the five dimensions of tangibility, reliability, responsiveness, assurance, and empathy in the SERVQUAL model proposed by Parasuraman, Zeithamal \& Berry (1988), which was employed as the theoretical framework for identifying which among five key factors has/have significant positive effects on the hotel's customer satisfaction. 


\subsection{Research Objectives}

The research objectives are as follows:

1) to identify the key factors affecting the hotel's customer satisfaction;

2) to evaluate the impact of each factor on the hotel's customer satisfaction.

\subsection{Significance of the Study}

The theoretical significance of this study is to deepen and widen the study on the applicability of SERVQUAL model into a case study of Chenzhou W-H-International Hotel, China. The practical significance of this study is to provide suggestions for improving the future decision-making for the customer satisfaction management of this hotel and also to provide a guide for other enterprises experiencing the similar situation with the mutual benefits for avoiding the mistakes in customer satisfaction management so as to improve the hotel's overall performance.

\subsection{The Scope and the Limitations}

This study only considered the five key factors conceptualized from the five dimensions of SERVQUAL model, namely hotel's facilities, service capability, service efficiency, service attitude, and breakfast to evaluate the degree of success in the customer satisfaction for the Chenzhou W-H-International Hotel. Other factors like the room rate could have a positive effect on the hotel customer satisfaction as well, which should be given much attention. On the other hand, this study considered only one hotel as a case study, thus it cannot represent the whole industry adequately. Due to the time and space constraints, this research utilized secondary data collected from the two online reservation websites (www.yilong.com and www.xiecheng.com), which have cooperation with the targeted hotel on the customers' online comments in 2017 and 2018.

\subsection{Theoretical Framework}

There are various theories in the study of customer satisfaction. Most of the previous studies focus on the introduction to different theories of customer satisfaction, then provide some related criticism for each theory. The idea of the measurement of customer satisfaction, including the summary of various theories of customer satisfaction and the models of customer satisfaction measurement, has been introduced while relevant criticism is also developed for each individual theory and the measurement of the customer satisfaction (for example, the theories of Customer Satisfaction). To be more specifically, the theories of customer satisfaction are classified broadly into three groups: Expectancy disconfirmation, Equity, and Attribution (Athiyaman, 2004). 
While four psychological theories were identified to explain the impact of expectancy or satisfaction: Assimilation, Contrast, Generalized Negativity, and Assimilation-Contrast (Anderson, 1973), another critic review of the theories was postulated to explain consumer satisfaction including the Expectancy-Disconfirmation Paradigm (EDP), the Value-Precept Theory, the Attribution Theory, the Equity Theory, the Comparison Level Theory, the Evaluation Congruity Theory, the Person-Situation-Fit model, the Performance Importance model, the Dissonance, and the Contrast Theory (Yüksel \& Yüksel, 2008).

\subsection{Literature Review}

In the area of case studies for the concept of customer satisfaction, the Critical Incident Approach has been used to perform a qualitative analysis of a large hotel in Sicily, the Sporting Club Hotel in the town Cefalù. The overall customer satisfaction level for the hotel and for each service supplied is evaluated through the analysis, which concluded with the discussion of the research results and offered a proposal for improving the customer satisfaction management of the hotel (Dominici \& Guzzo, 2010).

There are also studies aiming at investigating how customer satisfaction enhances customer loyalty in hotels. Lake Kivu Serena Hotel has been used as a case study. The data analysis method includes qualitative and quantitative analysis methods. From the findings of this study, it is evident that there are many factors influencing customer satisfaction. However, the major factors that influence customer satisfaction are mainly the quality of services offered by a hotel as well as customer relationship management (Mubiri, 2016).

The study of customer satisfaction has not limited to the hotel industry. A recent research has been conducted on the relationship between customer experience and customer satisfaction towards contemporary cafés in Klang Valley, Malaysia. Through a quantitative approach by using web survey technique to 80 respondents, the author has addressed the importance of customer experience by highlighting both functional and emotional elements in customer values, as well as emphasized on the concept of "third place" which appealed to be occurred in the contemporary cafés. Customer satisfaction turned out to be derived in the positive feelings resulting from the patrons such as customer delight and loyalty (Huang, 2017).

Relate to the rapid development of technology, many business models have been changed. As this trend grows, many researchers moved their focus to the study of how technology impact the industry. A new concept of business model named VHO (Virtual Hotel Operator) has been introduced by the research conducted in Indonesia focusing on how information quality and 
consumer reviews on the tool of Airy Rooms influencing consumer's behavior. This research examined the factors of the intention to buy on Airy Room using some key factors such as Review, and Information Quality. Structural equation model is used to test the relationship of these factors with Satisfaction, Perceived Value, and Purchase Intention. The result indicates that Information Quality and Consumers Reviews as the important precursors then Satisfaction and Perceived Value are the key determinants of purchase intention (Kurnia \& Sulistiani, 2019).

There are two areas in the hospitality industry where researchers and recent studies have paid much attention to, which include the environmental management, as well as the combination and application of the business English into the hotel industry. Studies targeting the environmental issues such as investigating on the effect of green hotel practice focusing on the moderating roles of consumer environmental world views (Jeon, Jeong, \& Kim, 2015); and examining the barriers or challenges that are faced in adopting more sustainable and responsible environmental management practices in hotels in KwaZulu- Natal, South Africa (Sucheran, 2018). Examples in the researches aimed at the application of business English in the hotel industry include the influence of cultural communication factors on English communication in an international service industry (Nualsri \& Chaiya, 2016); as well as studies about the English terms used in hotels and tourism places in Indonesia (Rahayu, 2017), and the analysis of linguistic characteristics of hotel homepages in Thailand (Sitthanakul, 2017). These studies have provided useful resources for researchers interested in the hotel industry and opened up more opportunities for further studies.

Early studies related to SERVQUAL model remain in a level of theoretical discussion. The concerns raised by Cronin and Taylor in 1992 and Teas in 1993 about the SERVQUAL model and the perceptions-minus-expectations specification invoked by it is to operationalize service quality. In response, the validity and alleged severity of many of those concerns which are questionable are being demonstrated with a set of research directions for addressing unresolved issues and adding to the understanding of service quality assessment (Parasuraman, et al., 1994,). Meanwhile, a detailed examination of the model is provided together with suggested areas for further research to improve its applicability to hospitality and tourism (Mill, 2011).

SERVQUAL model has been applied in many recent researches on the study of service quality and customer satisfaction. Service quality questionnaire for the hotel industry was first developed in Mauritius (Ramsaran, 2006). The possibilities and specifications of using the SERVQUAL model in service quality management in hotel industry are also a development to 
the SERVQUAL model (Ryglová, Vajčnerová, Šácha, 2011). The SERVQUAL model is also applied to measure the level of customer satisfaction on Indian Hotel Industry (Sharma, 2014) and Tirana hotels to measure the hotel guest satisfaction (Godolja \& Spaho, 2014). While, an analysis of hospitality sector in Goa was conducted using the same model (Renji, 2015).

On the selection from different theories and measures of customer satisfaction, the SERVQUAL model stands out to be the robust tool to measure service quality. However, most of the previous studies on customer satisfaction and the application of the SERVQUAL model were conducted through questionnaires and surveys, not including the confirmatory factor analysis. In this study, multiple linear regression analysis has been used to testify the relationship between the five key factors conceptualized from the five dimensions of SERVQUAL model and the degree of customer satisfaction.

\section{Conceptual Framework and Hypotheses}

\subsection{Conceptual Framework}

Since the study focused on the customer satisfaction management of the Chenzhou W-HInternational Hotel, the following factors were tested from the five dimensions of the SERVQUAL model:

- Tangibility: hotel's facilities (HF);

- Reliability: service capability (SC);

- Responsiveness: service efficiency (SE);

- Assurance: service attitude (SA);

- Empathy: breakfast (BF).

SPSS (19.0 version) was used for multiple linear regression analysis to identify the degree of each factor affecting the customer satisfaction. The multiple linear regression model and its estimation using ordinary least squares (OLS) is undoubtedly the most widely used tool in econometrics. It allows us to estimate the relation between a dependent variable and a set of explanatory variables (Schmidheiny, 2018).

The derived regression equation:

$$
\text { Customer Satisfaction }(\mathrm{CS})=\mathrm{b}_{0}+\mathrm{b}_{1}(\mathrm{HF})+\mathrm{b}_{2}(\mathrm{SC})+\mathrm{b}_{3}(\mathrm{SE})+\mathrm{b}_{4}(\mathrm{SA})+\mathrm{b}_{5}(\mathrm{BF})+\varepsilon
$$

The dependent variable for this equation is customer satisfaction, while the independent variables are hotel's facilities, service capability, service efficiency, service attitude, and 
breakfast. The data collection process for each dependent variable and independent variables is discussed in the data section.

\begin{tabular}{|c|}
\hline Hotel Facilities \\
Service Capability \\
Service Efficiency \\
Service Attitude \\
Breakfast
\end{tabular}

Figure 1: Conceptual Framework

\subsection{Hypotheses}

Hypothesis 1: The hotel's facilities have significant positive effects on customer satisfaction.

In the case study about Borobudur Hotel in Jakarta, questionnaires were distributed directly to 360 customers to determine the influence of its facilities on its customer satisfaction. After the path analysis, the results indicate that its facilities have a significant and direct influence towards its customer satisfaction (Nurcahyo, Fitriyani \& Hudda, 2017).

Hypothesis 2: The hotel's service capability has significant positive effects on its customer satisfaction.

According to Parasuraman et al. (1988), service quality can be defined as the capacity of the company to conform with or outdo customer expectations. It is the deviation between the customer's expectation of service and perceived service (Zeithaml, Parasuraman \& Berry, 1990). Good quality of service will have a positive influence on profitability by elevating the customer base of a firm (Rauch et al., 2015).

Hypothesis 3: The hotel's service efficiency has significant positive effects on its customer satisfaction.

Morrison and Mahoney (2002) proposed an inspecting method that can enhance the quality of services offered by hotels. The evaluation technique is based on the responsiveness of employees when it comes to handling customer requests. They suggest that measuring the responsiveness of an employee is a good way to monitor the effectiveness of employees in terms 
of the speed service delivery. In this way, customers will feel that their needs are met in time. Responsiveness can also show the hotel's commitment to customer request and willingness to act on issues that may cause dissatisfaction.

Hypothesis 4: The hotel's service attitude has significant positive effects on its customer satisfaction.

In the study of customer relations and services, service attitude and the quality of the staff was examined and proved to be important to customers. Customer service staff should pay extra attention to take care of, and satisfy the emotional needs of customers (Penfold, 2014).

Hypothesis 5: The hotel's breakfast has significant positive effects on its customer satisfaction.

Among the services provided by hotels and hostels, breakfast stands out. This is usually the only meal included in the room rate, and stands out as an amenity that has a major influence on consumers' choice of a hotel. Because it is the first meal of the day, after a long period of fasting during sleep, breakfast is of particular importance (Barreto \& Cé, 2014; Trancoso, Cavalli, \& Proença, 2010). In hotels, breakfast is also one of the most important moments of the day, for it arouses the curiosity of guests and can be strategic to the company. It is possible to make an impression and surprise the customer during breakfast both in terms of product and service quality. It is also a unique moment for the hotelier to seduce the guest (Trancoso, 2008).

\section{Research Methodology}

\subsection{Sources of Data}

The data for this study is the customers' online comments in 2017 and 2018 from the two online reservation websites (www.xiecheng.com and www.yilong.com) which have a contract with the Chenzhou W-H-International Hotel. These two websites are the most popular online booking websites in China and all of the online bookings for the Chenzhou W-H-International Hotel were placed from these two websites. The SERVQUAL model is the theoretical framework for the study, and the SPSS (19.0 version) is the instrument of processing the data for further analysis.

The data collection process for the dependent variable customer satisfaction was to calculate the average customers' rating for the hotel's overall performance from the two websites in each month of 2017 and 2018. While, the data collection process for the independent variable hotel's facilities, service capability, service efficiency, service attitude, and breakfast were to 
record the customers' online comments from the two websites about each variable in every month of 2017 and 2018.

\subsection{Data Analysis}

The current total number of the customers' online comments for Chenzhou W-HInternational Hotel from the website of www.yilong.com is 1461, with the overall rating of 4.5/5.0; while from the website of www.xiecheng.com, the up-to-date total number of customers' online comments is 1550 , with the overall rating of 4.4/5.0. In the year 2018, there were 165 comments from the website of www.yilong.com, and 176 comments from the website of www.xiecheng.com. For year 2017, there was a total of 169 comments from the website of www.yilong.com, and 295 comments from the website of www.xiecheng.com.

All the calculation and data recording process are based on the above information.

Below is the data table of the summary of results for 2017 and 2018.

Table 1 shows the customers' online comments in every month of 2017.

Table 1: Customers' Online Comments for 2017

\begin{tabular}{|c|c|c|c|c|c|c|}
\hline \multicolumn{2}{|c|}{ Overall Ratings } & HF & SC & SE & SA & BF \\
\hline Jan. & 4.1 & 4.5 & 3.8 & 3.8 & 4.4 & 3.8 \\
\hline Feb. & 4.3 & 4.4 & 2.7 & 3.9 & 3.6 & 4.3 \\
\hline Mar. & 4.4 & 4.8 & 4.6 & 4 & 4 & 4.5 \\
\hline Apr. & 4.5 & 5 & 4.3 & 4.5 & 4.7 & 4 \\
\hline May & 4.5 & 4.4 & 3.7 & 4.1 & 3.9 & 4.3 \\
\hline June & 4.6 & 5 & 4.7 & 4.4 & 3.9 & 3.9 \\
\hline July & 4.8 & 4.6 & 4.5 & 4.5 & 4.6 & 4.3 \\
\hline Aug. & 4.7 & 4.5 & 4.9 & 4.3 & 5 & 4.8 \\
\hline Sept. & 4.5 & 5 & 4 & 3.5 & 4.3 & 4.5 \\
\hline Oct. & 4.5 & 5 & 3.6 & 4.2 & 4.4 & 3.8 \\
\hline Nov. & 4.5 & 5 & 4 & 3.5 & 4.4 & 4.5 \\
\hline Dec. & 3.5 & 4 & 2.6 & 2.8 & 3 & 2.9 \\
\hline Average & $\mathbf{4 . 4}$ & $\mathbf{4 . 7}$ & $\mathbf{4 . 0}$ & $\mathbf{4 . 0}$ & $\mathbf{4 . 2}$ & $\mathbf{4 . 1}$ \\
\hline
\end{tabular}


In the data of year 2017, only the key factor of Hotel Breakfast has been rated relatively high (4.7/5.0). The average score for other four factors shows that further improvements are needed if the hotel wants to obtain a better customer satisfaction.

Table 2 reveals the customers' online comments in every month of 2018.

Table 2: Customers' Online Comments for 2018

\begin{tabular}{|c|c|c|c|c|c|c|}
\hline \multicolumn{2}{|c|}{ Overall Ratings } & HF & SC & SE & SA & BF \\
\hline Jan. & 4.6 & 4.5 & 3.8 & 3.8 & 4.4 & 3.8 \\
\hline Feb. & 4.2 & 4.4 & 2.7 & 3.9 & 3.6 & 4.3 \\
\hline Mar. & 4.5 & 4.8 & 4.6 & 4 & 4 & 4.5 \\
\hline Apr. & 4.2 & 5 & 4.3 & 4.5 & 4.7 & 4 \\
\hline May & 4 & 4.4 & 3.7 & 4.1 & 3.9 & 4.3 \\
\hline June & 4.4 & 5 & 4.7 & 4.4 & 3.9 & 3.9 \\
\hline July & 4.8 & 4.6 & 4.5 & 4.5 & 4.6 & 4.3 \\
\hline Aug. & 4.1 & 4.5 & 4.9 & 4.3 & 5 & 4.8 \\
\hline Sept. & 4.1 & 5 & 4 & 3.5 & 4.3 & 4.5 \\
\hline Oct. & 4.4 & 5 & 3.6 & 4.2 & 4.4 & 3.8 \\
\hline Nov. & 4.5 & 5 & 4 & 3.5 & 4.4 & 4.5 \\
\hline Dec. & 4.1 & 4 & 2.6 & 2.8 & 3 & 2.9 \\
\hline Average & $\mathbf{4 . 3}$ & $\mathbf{4 . 7}$ & $\mathbf{4 . 0}$ & $\mathbf{4 . 0}$ & $\mathbf{4 . 2}$ & $\mathbf{4 . 1}$ \\
\hline
\end{tabular}

In the data of year 2018, the online customer satisfaction results did not change much. Hotel Breakfast has maintained its high performance, however other four factors did not improve from year 2017 to 2018 .

\section{Results and Discussion}

The research results are listed in Table 3 (Multiple regression results). 
Table 3: Multiple Regression Results, 2017 and 2018

\begin{tabular}{|c|c|c|}
\hline Independent Variable & Coefficient & Standard Error \\
\hline Hotel Facilities & 0.146 & 0.092 \\
\hline Service Capability & $0.443^{*}$ & 0.092 \\
\hline Service Efficiency & -0.207 & 0.071 \\
\hline Service Attitude & $0.260^{*}$ & 0.057 \\
\hline Breakfast & 0.092 & 0.117 \\
\hline Constant & 0.480 & 0.680 \\
\hline F=10.077* & & \\
\hline Pseudo R2=0.263 & & \\
\hline
\end{tabular}

*Significant at $5 \%$ level

Hotel Facilities (HF) has a positive relation to Customer Satisfaction (CS). CS increases or decreases when HF increases or decreases. However, the effect of HF on CS is +0.146 is not significant at $\mathrm{a}=0.05(\mathrm{sig}=0.130)$.

Service Capability (SC) has a positive effect on CS, which equals to 0.443 which is significant at $\mathrm{a}=0.05(\mathrm{sig}=0.000)$.

Service Efficiency (SE) has a negative effect on CS, which equals to -0.027 and not significant at $\mathrm{a}=0.05(\mathrm{sig}=0.712)$.

Service Attitude (SA) has a positive effect on CS, which equals to 0.260 and this effect is significant at $\mathrm{a}=0.05(\mathrm{sig}=0.000)$.

Breakfast (BF) has a positive effect on CS, which equals to 0.092. However, this effect is not significant at $\mathrm{a}=0.05(\mathrm{sig}=0.446)$.

$\mathrm{R}$ Square $=0.737$, which means that $73.7 \%$ of relevant variables have been included to affect CS and $26.3 \%$ of relevant variables are yet to be identified.

$\mathrm{F}-$ Value $=10.077, \mathrm{sig}=0.000$. The result of the F-test shows that the derived equation is a valid tool to predict CS for the next period.

\section{Summary, Conclusions and Recommendations}

Through the analysis of the secondary data provided by the two associated online reservation websites (www.yilong.com and www.xiecheng.com) of customers' online comments 
for 2017 and 2018 regarding to the targeted Chenzhou W-H-International Hotel, all of the five hypotheses have been tested where only two of the five hypotheses have been verified.

The following recommendations are proposed based on the results and discussions:

- On Service Capability. Most of the customers' online comments towards this area is about the cleanness of the hotel rooms and issues regarding to the interior environment. Thus, the hotel should improve the level of cleanness in all rooms and also elevate the standard of hotel internal environment which is a major concern for customer satisfaction. Encourage all the employees to contribute and double check the room quality on a daily basis, especially the management team.

- On Service Attitude. The majority of complains from the customers' online comments were pointed to the bad experiences with the hotel's front desk and housekeeping employees. To solve this problem, the human resource department of the hotel should be aware of the competency of the employees starting from the recruiting process. Involve the specific training procedure related to offering polite and trustworthy services to the customers. Sufficient practice on handling different situations for the new employees should be a requirement before serving at the real position because frontline employees have the direct communication with the customers.

\section{References}

Anderson, R. E. (1973). Consumer dissatisfaction: The effect of disconfirmed expectancy on perceived product performance. Journal of Marketing Research. 10: 38-44. https://doi.org/10.1177/002224377301000106

Athiyaman, A. (2004). Antecedents and consequences of student satisfaction with university services: A longitudinal analysis. Academy of Marketing Studies Journal. 8 (1). pp. 89105.

Dominici, G. \& Guzzo, R. (2010). Customer satisfaction in the hotel industry: A case study from Sicily. International Journal of Marketing Studies. Vol. 2, No. 2, pp. 3-12. https://doi.org/10.5539/ijms.v2n2p3

Godolja, M. \& Spaho, A. (2014). Measuring Hotel Guest Satisfaction Using SERVQUAL Method: A Study in Tirana Hotels. MBA thesis of University of Tirana.

Hayes, D. K. \& Ninemeier J. D. (2009). Human Resources Management in the Hospitality Industry. Hoboken, New Jersey: John Wiley \& Sons, Inc. 
Hoque, K. (2000). Human Resources Management in the Hotel Industry. London: Routledge.

Huang, L. V. (2017). Malaysian Café Culture: The Relationship between Customer Experience and Customer Satisfaction towards Contemporary Cafés. PEOPLE: International Journal of Social Sciences, 3(2). Retrieved from https://grdspublishing.org/index.php/people/article/view/691 https://doi.org/10.20319/pijss.2017.32.15821602

Ivanovic, S. \& Blazevic, M. (2009). Human resource management in the hospitality industry. Tourism and Hospitality Management. Vol. 15, No. 1, pp. 107-116.

Krstić, S. (2016). Human Resources Management in Hotel Industry: The Analysis of Current Practices in Serbia. SICTION 2016. Quality as a basis for tourism destination competitiveness. 174-180. https://doi.org/10.15308/Sitcon-2016-174-180

Kurnia, G., \& Sulistiani, P. B. (2019). Influencing Consumer's Behavior: Perspective of Information Quality and Consumers Reviews on Airyrooms. PEOPLE: International Journal of Social Sciences, 5(1). Retrieved from https://grdspublishing.org/index.php/people/article/view/1868 https://doi.org/10.20319/pijss.2019.51.254266

Mi Jeon, S., Jeong, W., \& Kim, D. (2015). The Effects of Green Hotel Practices On Hotel Image, Visit Intention, and Word-of-Mouth: Focusing on the Moderating Roles of Consumer Environmental Worldviews. PEOPLE: International Journal of Social Sciences, 1(1). Retrieved from https://grdspublishing.org/index.php/people/article/view/386 https://doi.org/10.20319/pijss.2015.s11.491499

Mill, R. C. (2011). A comprehensive model of customer satisfaction in hospitality and tourism: Strategic implications for management. International Business \&Economics Research Journal. Vol. 1, No. 6, pp. 7-18. https://doi.org/10.19030/iber.v1i6.3942

Mubiri, J. B. (2016). Customer Satisfaction in Hotel Services. MBA thesis of JAMK University of Applied Sciences.

Nualsri, S., \& Chaiya, P. (2016). The Influence of Cultural Communication Factors on English Communication in an International Service Industry. PEOPLE: International Journal of Social Sciences, 2(1). Retrieved from https://grdspublishing.org/index.php/people/article/view/273 https://doi.org/10.20319/pijss.2016.s21.355369 
Nurcahyo, R., Fitriyani, A. \& Hudda, I. N. (2017). The Influence of facility and service quality towards customer satisfaction and its impact on customer loyalty in Borobudur Hotel in Jakarta. Binus Business Review. 1, 23-29. https://doi.org/10.21512/bbr.v8i1.1790

Parasuraman, A., Zeithaml, V. A., \& Berry, L. L. (1988). SERVQUAL: A multiple-item scale for measuring consumer perceptions of service quality. Journal of Retailing. Vol.64, No.1, pp. 12-40.

Parasuraman, A., Zeithaml, V. A., \& Berry, L. L. (1994). Reassessment of expectations as a comparison standard in measuring service quality: Implications for further research. Journal of Marketing Studies. 58, 111-124. https://doi.org/10.2307/1252255 https://doi.org/10.1177/002224299405800109

Rahayu, A. U. (2017). The English Terms used in Hotels and Tourism Places and their Correspondences in Indonesian. PEOPLE: International Journal of Social Sciences, 3(2). Retrieved from https://grdspublishing.org/index.php/people/article/view/712 https://doi.org/10.20319/pijss.2017.32.16931706

Ramsaran-Fowdar, R. R. (2006). Developing a service quality questionnaire for the hotel industry in Mauritius. Journal of Vacation Marketing. 1, 21. https://doi.org/10.1177/1356766706071203

Renji, G. A. (2015). Servqual Model: An Analysis of Hospitality Sector in Goa. Asian Journal of Managerial Science. 1, 23-26.

Ryglová, K., Vajčnerová, I. \& Šácha, J. (2011). SERVQUAL Potential for Quality Management in Hotel Services. Acta univ. agric. et silvic. Mendel. Brun. LX, 2, 307-314. https://doi.org/10.11118/actaun201260020307

Schmidheiny, K. (2018). The Multiple Linear Regression Model. MBA thesis of Universität Basel.

Sharma, C. (2014). A service quality model applied on Indian hotel industry to measure the level of customer satisfaction. International Journal of Science and Research (IJSR). 3, 80485.

Sitthanakul, K. (2017). An Analysis of Move and Linguistic Characteristics of Hotel Homepages. PEOPLE: International Journal of Social Sciences, 3(2). Retrieved from https://grdspublishing.org/index.php/people/article/view/649 https://doi.org/10.20319/pijss.2017.32.10571076 
Soutar, G.N. (2001). Service quality, customer satisfaction, and value: an examination of their relationships. In J. Kandampully, C. Mok, \& B. Sparks (Eds.) Service Quality Management in Hospitality, Tourism, and Leisure. New York: The Haworth Hospitality Press, 103.

Sucheran, D. R. (2018). Barriers to Environmental Management in Hotels in Kwazulu- Natal, South Africa. PEOPLE: International Journal of Social Sciences, 3(3). Retrieved from https://grdspublishing.org/index.php/people/article/view/1055 https://doi.org/10.20319/pijss.2018.33.13521364

Teas, K.R. (1994). Expectations as a comparison standard in measuring service quality: An assessment of a reassessment. Journal of Marketing Studies. 58, 132-139. https://doi.org/10.1177/002224299405800111 https://doi.org/10.2307/1252257

Yüksel, A. \& Yüksel, F. (2008). Consumer satisfaction theories: A critical review. In Yüksel, Atila (Ed.). Tourist Satisfaction and Complaining Behavior: Measurement, and Management Issues in the Tourism and Hospitality Industry. New York: Nova Science Publishers.

Zeithaml, Valarie A., Parasuraman, A., \&Berry, L.L. (1990). Delivering Quality Service: Balancing Customer Perceptions and Expectations. New York: The Free Press. 